\title{
A STUDY OF THE LEADERSHIP BEHAVIORS REPORTED BY PRINCIPALS AND OBSERVED BY TEACHERS AND ITS RELATION WITH PRINCIPALS MANAGEMENT EXPERIENCE
}

Vali Mehdinezhad, Zaid Sardarzahi

University of Sistan and Baluchestan, Iran

Highlights
- Leadership behaviors reported by principals and observed by teachers and its relationship with management experience of principals
- The teachers describe the leadership behaviors of their principals relatively good
- The principals themselves evaluated their leadership behaviors as very good
- Significant difference between the views and evaluations of teachers and principals on all components of leadership behaviors of principals,
except empowerment

\section{Abstract}

The present paper aims to study the leadership behaviors reported by principals and observed by teachers and its relationship with management experience of principals. A quantitative method used in this study. Target population included all principals and teachers of guidance schools and high schools in Dashtiari District, Iran. A sample consisted of 46 principals and 129 teachers were selected by stratified sampling and simple random sampling methods. Leadership Behavior Description Questionnaire (LBDQ) developed by Kozes and Posner (2001) was used for data collection. The obtained data were analyzed using one sample and independent t-test, correlation coefficient and crosstabs pearson chi-square test. The results showed that teachers describe the leadership behaviors of their principals relatively good. However, the principals themselves evaluated their leadership behaviors as very good. In comparison between leadership behaviors self-reported by principals and those observed by teachers, it was found that there is a significant difference between the views and evaluations of teachers and principals on all components of leadership behaviors of principals, except empowerment. In fact, principals have described their leadership behaviors at a better and more appropriate level than what teachers have done. From the perspective of both teachers and principals, there is no significant relationship between none of the components of leadership behaviors and management experience of principals.

\section{Keywords}

Leadership behaviors, management experience, principals, teachers
Article type

Full research paper

Article history

Received: February 26, 2015

Received in revised form: June 17, 2015

Accepted: June 28, 2015

Available on-line: June 30, 2015

Mehdinezhad V., Sardarzahi Z. (2015) "A Study of The Leadership Behaviors Reported by Principals
and Observed by Teachers and its Relation with Principals Management Experience", Journal
on Efficiency and Responsibility in Education and Science, Vol. 8, No. 2, pp. 48-53, online ISSN 1803-1617,
printed ISSN 2336-2375, doi: 10.7160/eriesj.2015.080203.

\section{Introduction}

The word of leadership is more like the words freedom, love, and peace. Although each person intuitively knows the meaning of each of these words, any of these words can have different definitions for different people. Once everyone starts to define leadership, he/she immediately realizes that there are many definitions of leadership. In the last fifty years, more than sixtyfive different systematic classifications have been provided to define the criteria of leadership (Fleishmann et al., 1991). In adefinition with emphasis on the relationships between people, leadership is defined as influencing the subordinates through communicating with them in order to achieve organizational goals (Alvani, 1993). Knowing the great roles of technology today, educational leaders are challenged to find which leadership practices effectively influence teachers to improve their instructional techniques and to continue their professional development and growth, in addition to focusing their attention, and the attention of the entire school community, on student learning (Jabor et al., 2013).

Previous studies conducted on leadership behaviors have obtained various results. Alaei (2010) compared the importance of leadership and managerial behaviors from the perspective of teachers and principals of schools in Zahedan. The results showed that teachers and principals value the leadership and managerial behaviors the same. However, among the components of leadership, principals believed that modeling is more important than managerial behaviors. Both teachers and principals stated that managerial behaviors outweigh challenging and female principals considered more value for managerial and leadership behaviors than men. Goudarzi (1996) stated that there is no significant difference between principals of public and private schools in terms of effectiveness of leadership behaviors and also there is no significant relationship between the academic degree of principals and efficiency of their leadership behaviors. The findings of Naeemollah and Hafiz (2010) showed that female manages show managerial behaviors better than men. Pingle and Cox (2007) stated that, from the perspective of teachers, those principals are more successful that exhibit higher levels of leadership behaviors. Carr (1988) found that male and female principals of public high schools have different views on leadership behaviors (including mutual trust, mutual respect, friendship, and cordiality between themselves and employees under their supervision). Different demographic parameters such as age, education, and work experience have a significant impact on attitude of principals towards leadership. Manning (2004) showed that female principals pay more attention to the activities of teachers and understand their expectations better than male principals. Umbach (1993) found a significant difference between views of faculty members about leadership behavior of male and female principals. The results of Long 
(1991) suggested that empowering others is the most important leadership strategy in order to achieve the best personal performance, and other priorities, in order of preference, include inspiring a shared vision, modeling, reassuring, and challenging. Robinson (1996) studied the views of teachers on leadership behaviors of principals of primary schools and found a significant relationship between effectiveness of leadership behaviors of principals and their age, gender, and ethnicity. Findings of Berumen (1992) indicated that empowerment and reassuring are less used by principals. Ayman and Chemers (1983) used Leadership Behavior Description Questionnaire to study 142 employees in nine sections of a large industrial company in Iran in order to assess the generalizability of their leadership behaviors to the samples obtained in studies conducted in Europe and the US. The results of their study showed that Iranian employees believe that a good manager is one who is benevolent and treats the employees like a father. Dhanasobhon (1982) concluded that gender, educational background, and work experience in the present job have no effect on leadership styles observed in principals of high schools. Tanner (1981) found that factors that can easily be altered, such as leadership styles are more effective in leadership effectiveness rather than characteristics such as age, gender, race, and experience of principals or demographic characteristics of students. Since leaders and managers influence others through their behaviors, subordinates' impression of management and leadership is affected by leadership behaviors of leaders and managers. So, knowing the difference between leadership and managerial behaviors is very important in establishment of an organization, making organizational changes, and guiding organizational teams. Managers and leaders are different in their orientations towards objectives, business concepts, personal styles, and perceptions. The duty of educational leaders of schools is to improve education quality and students' learning and the role of school principals is to guide activities in order to achieve the objectives and establish a desired order and discipline in their school. Leadership is associated with changes but management is looking for maintenance activities. Leaders not only see what affairs are seemingly but also see their hidden aspects.

The main purpose of this study was to evaluate the leadership behaviors of the schools' principals. In Kouzes and Posner's studies (2002b), effective leaders were able to 1) Model the way, 2) Inspire a shared vision, 3) Challenge the process, 4) Enable others to act, and 5) Encourage the heart.

According to Kouzes and Posner (2002a: 15) "Modeling the way is essentially about earning the right and the respect to lead through direct involvement and action. People first follow the person, then the plan". Kouzes and Posner (2006: 93), "the quest for leadership, therefore, is first an inner quest to discover who you are, and it's through this process of self-examination that you find the awareness needed to lead".

Leaders inspire a shared vision, the ability to anticipate opportunities and attract others in the field. According to Kouzes and Posner (2007: 18) "leaders breathe life into the hopes and dreams of others and enable them to see the exciting possibilities that the future holds. Leaders forge a unity of purpose by showing constituents how the dream is for the common good. Kouzes and Posner (2003: 13) believed that "Leaders inspire a shared vision by envisioning the future and enlisting others in a common vision".

According to Kouzes and Posner (2003: 4) effective leaders refuse to settle for the status quo, so they experiment and take risks in an effort to improve organizations. In fact, "Leaders challenge the process by searching for opportunities and by experimenting, taking risks, and learning from mistakes". Covey (2005: 33) found out "Leaders who challenge the process create a safe environment where the staff feels comfortable when they experiment only to fail. Effective leaders increase confidence in their staff by building on successes and accepting failures as critical learning opportunities".

Enable others to act is a team effort. Leaders make possible for others to do good work. Therefore, Empowerment is crucial to achieve results (Satia et al, 2014: 144). According to Kouzes and Posner (2007) effective leaders create an atmosphere of trust so that followers will feel capable enough to work towards meeting goals.

Leaders who want to encourage the heart must model the behaviors described within the first six essentials. Setting the example for encouraging the heart begins with giving oneself permission to do so (Kouzes and Posner, 1999). Kouzes and Posner (2003) included seven essential components in describing encourage the heart as set clear standards, expect the best, pay attention, personalize recognition, tell the story, celebrate together, and set the example.

According to all mentioned above, the present study seeks to answer the following questions:

- What's the teachers' perception of leadership behaviors of their principals?

- What's the principals' perception of their own leadership behaviors?

- Is there any significant difference between leadership behaviors reported by principals themselves and those observed by teachers?

- Is there a relationship between leadership behaviors and management experience from the perspective of principals and teachers?

\section{Materials and Methods}

The present study was a descriptive-correlative research. Target population included all principals and teachers $(\mathrm{N}=315)$ of middle and high schools in Dashtiari District, Iran. According to Krejcie and Morgan (1970) of determining sample size, 175 subjects were selected as the sample by stratified sampling and simple random sampling methods (Table 1 and Table 2).

\begin{tabular}{|c|c|c|c|}
\hline \multicolumn{2}{|c|}{ Group } & Population & Sample \\
\hline \multirow{3}{*}{ Teachers } & Male & 155 & 86 \\
\cline { 2 - 4 } & Female & 78 & 43 \\
\hline \multirow{2}{*}{ Principals } & Male & 47 & 26 \\
\cline { 2 - 4 } & Female & 35 & 20 \\
\hline \multirow{3}{*}{ Total } & Male & 202 & 112 \\
\cline { 2 - 4 } & Female & 113 & 63 \\
\cline { 2 - 4 } & & 315 & 175 \\
\hline
\end{tabular}

Table 1: The population and sample size 


\begin{tabular}{|c|c|c|c|}
\hline \multicolumn{2}{|c|}{ Group } & $\mathrm{N}$ & $\%$ \\
\hline \multirow{4}{*}{ Age } & $20-25$ & 20 & 11.4 \\
\cline { 2 - 4 } & $26-30$ & 64 & 36.6 \\
\cline { 2 - 4 } & $31-35$ & 50 & 28.6 \\
\cline { 2 - 4 } & $36-40$ & 41 & 23.4 \\
\hline \multirow{7}{*}{ Education level } & $\begin{array}{c}\text { Associate's } \\
\text { degree }\end{array}$ & 58 & 33.1 \\
\cline { 2 - 4 } & $\begin{array}{c}\text { Bachelor's } \\
\text { degree }\end{array}$ & 107 & 61.1 \\
\cline { 2 - 4 } & $\begin{array}{c}\text { Master's } \\
\text { degree }\end{array}$ & 10 & 5.8 \\
\hline \multirow{5}{*}{$\begin{array}{c}\text { Job experience } \\
\text { <=5 year }\end{array}$} & $5-10$ year & 94 & 16.0 \\
\cline { 2 - 4 } & $>=11$ year & 53 & 30.3 \\
\hline \multirow{2}{*}{$\begin{array}{c}\text { Management experience } \\
\text { (Principals) }\end{array}$} & $>=5$ year & 26 & 56.5 \\
\cline { 2 - 4 } & $>5$ year & 20 & 43.5 \\
\hline
\end{tabular}

Table 2: The details of sample $(\mathrm{N}=175)$

According to the nature of the research topic, Leadership Behavior Description Questionnaire (LBDQ) developed by Kozes and Posner (2001) was used in two forms of self-reporting by principals and leadership behaviors observed by teachers. This questionnaire consists of 30 items in a five-point Likert from very low $=1$ to very high $=5$. The minimum score for each component is 6 and the highest score was 30 . The questionnaire had 5 components and each had 6 items which included: model the way, inspire shared visions, challenge the process, enable others to act, and encourage the heart. Internal consistency of the questionnaire was confirmed by Cronbach's alpha coefficient. This coefficient was obtained 0.97 for questionnaire form of leadership behaviors observed by teachers and 0.74 for questionnaire form of self-reporting by principals. A number of experts in the field of Educational Sciences confirmed the validity of this questionnaire. Data analysis was done using statistical methods such as frequency, mean, standard deviation, correlation coefficient test, one sample, independent t-test and crosstabs pearson chi-square test in SPSS 20 software.

\section{Results}

The first question: What's the teachers'perception of leadership behavior of their principals?

\begin{tabular}{|c|c|c|c|c|c|c|}
\hline Variables & Mean & Std.D & T-Value & t-test & df & Sig. \\
\hline Model the way & 23.93 & 4.68 & & 14.36 & & 0.001 \\
\hline Inspire a shared vision & 23.83 & 4.85 & & 13.63 & & 0.001 \\
\hline Challenge the process & 23.33 & 5.27 & 18 & 11.47 & 128 & 0.001 \\
\hline Enable others to act & 22.84 & 5.23 & & 10.49 & & 0.001 \\
\hline Encourage the heart & 23.95 & 5.07 & & 13.31 & & 0.001 \\
\hline Total & 117.88 & 24.08 & 90 & 47.09 & & 0.001 \\
\hline
\end{tabular}

Table 3: One sample t-test about teachers' perception of leadership behavior of their principals $(\mathrm{N}=129)$

The results of one sample t-test in table 3 show that in total and in all components of leadership behaviors, the calculated mean is more than the assumed mean (T-Value) and significant $(\mathrm{P}<0.001)$. In fact the teachers surveyed rated their principals highly in each of the five leadership categories. The mean scores were between 23.33 and 23.95. The standard deviations ranged from 4.68 to 5.27 . Teachers in this study rated their principals most favorably in the leadership area of encourage the heart and model of way with a mean score of 23.95 and 23.93.Teachers in this study rated their principals least favorably in the area of enable others to act with a mean score of 22.84. Overall, it appears that teachers in this study view their principals' leadership behaviors favorably.

The second question: What's the principals'perception of their own leadership behaviors?

\begin{tabular}{|c|c|c|c|c|c|c|}
\hline Variables & Mean & Std.D & T-Value & t-test & df & Sig. \\
\hline Model the way & 26.23 & 7.83 & & 7.13 & & 0.001 \\
\hline Inspire a shared vision & 25.50 & 3.01 & & 16.86 & & 0.001 \\
\hline Challenge the process & 24.95 & 2.94 & 18 & 16.02 & 45 & 0.001 \\
\hline Enable others to act & 24.43 & 2.92 & & 14.68 & & 0.001 \\
\hline Encourage the heart & 25.84 & 2.45 & & 21.65 & & 0.001 \\
\hline Total & 126.84 & 19.15 & 90 & 76.34 & & 0.001 \\
\hline
\end{tabular}

Table 4: One sample t-test about the principals' perception of their own leadership behaviors ( $N=46$ )

According to table 4 , in total and in all components of leadership behaviors, the calculated mean is more than the assumed mean (T-Value) and significant $(\mathrm{P}<0.001)$. In other words, the principals surveyed rated themselves relativity very high on each of the five leadership components. The mean scores ranged between 26.23 and 24.43. Principals in this study rated themselves most favorably in the leadership area of model the way with a mean score of 26.23. Principals also in this study rated themselves least favorably in the area of enable others to act with a mean score of 24.43. Based on the data, principals in this study view their overall leadership behaviors very favorably.

The third question: Is there any significant difference between leadership behaviors reported by principals themselves and those observed by teachers?

\begin{tabular}{|c|c|c|c|c|c|c|c|}
\hline Variables & G. & $\mathrm{N}$ & Mean & Std.D & t-test & df & Sig. \\
\hline \multirow{2}{*}{$\begin{array}{c}\text { Model the } \\
\text { way }\end{array}$} & T. & 129 & 23.9302 & 4.68739 & -2.369 & & .019 \\
\cline { 2 - 5 } & $\mathrm{P}$. & 46 & 26.2391 & 7.83208 & & & \\
\hline $\begin{array}{c}\text { Inspire a } \\
\text { shared vision }\end{array}$ & $\mathrm{T}$. & 129 & 23.8295 & 4.85754 & -2.185 & & .030 \\
\cline { 2 - 6 } & $\mathrm{P}$. & 46 & 25.5000 & 3.01662 & & & \\
\hline $\begin{array}{c}\text { Challenge the } \\
\text { process }\end{array}$ & $\mathrm{T}$. & 129 & 23.3333 & 5.27721 & -1.977 & & .050 \\
\cline { 2 - 6 } $\begin{array}{c}\text { Enable others } \\
\text { to act }\end{array}$ & $\mathrm{P}$. & 46 & 24.9565 & 2.94359 & & 173 & \\
\hline & $\mathrm{P}$. & 46 & 24.3261 & 2.92160 & & & \\
\hline \multirow{2}{*}{$\begin{array}{c}\text { Encourage } \\
\text { the heart }\end{array}$} & $\mathrm{T}$. & 129 & 23.9535 & 5.07731 & -2.428 & & .016 \\
\cline { 2 - 5 } & $\mathrm{P}$. & 46 & 25.8478 & 2.45825 & & & \\
\hline \multirow{2}{*}{ Total } & $\mathrm{T}$. & 129 & 117.8837 & 24.08891 & -3.033 & & .018 \\
\cline { 2 - 5 } & $\mathrm{P}$. & 46 & 126.8696 & 14.02634 & & & \\
\hline
\end{tabular}

Table 5: Independent t-test about difference between leadership behaviors reported by principals themselves and those observed by teachers $(\mathrm{N}=175)$

The results of independent t-test show that there is a significant difference between the views and evaluations of teachers and principals on all components of leadership behaviors of principals, except enable others to act. In fact, the teachers rated the principals lower in all categories than the principals rated themselves. The teachers and principals have the same rating to Enable others to act.

The fourth question: Is there a relationship between leadership behaviors and management experience from the perspective of principals and teachers? 


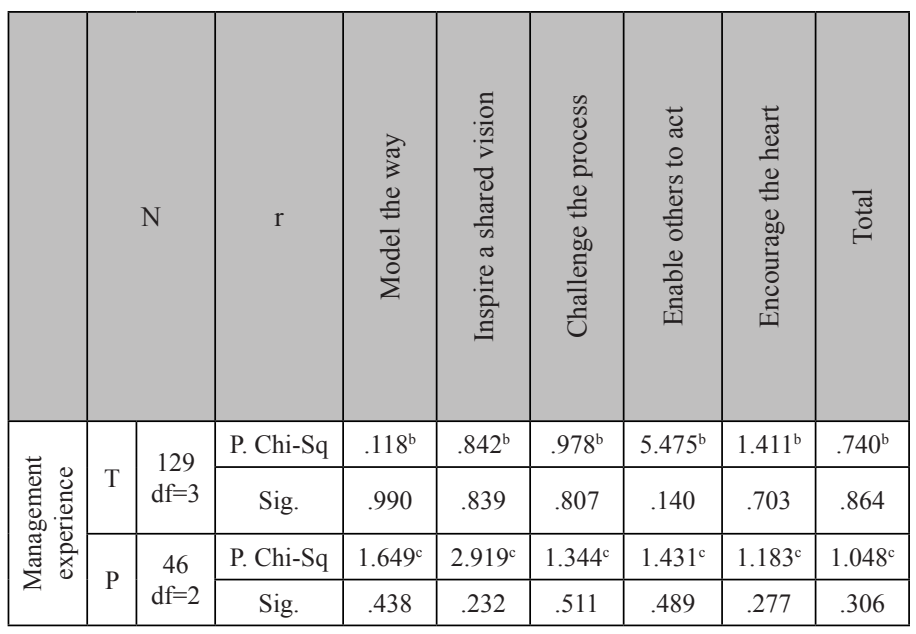

Table 6: Crosstabs Pearson Chi-Square test on the relationship between leadership behaviors and management experience from the perspective of principals and teachers $(N=175) P=$ Principals $\mathbf{T}=$ Teachers

b. 2 cells (25.0\%) have expected count less than 5. The minimum expected count is .85.

c. 2 cells $(33.3 \%)$ have expected count less than 5 . The minimum expected count is . 48 .

The results of table 6 show that there is no significant relationship between none of the components of leadership behaviors and management experience from the perspective of principals. In other words, leadership behaviors of experienced $(>5)$ and inexperienced $(>=5)$ principals are relatively the same and generally acceptable.

According to table 6, there is no significant relationship between none of the components of leadership behaviors and management experience from the perspective of teachers. In other words, teachers believe that leadership behaviors of both experienced $(>5)$ and inexperienced $(>=5)$ principals are relatively passable. In overall, based on the results it can be deduced, there is no any difference because the principals and teachers don't evaluate principals better when they have $>5$ experiences or unlike.

\section{Discussion}

The analysis of data from the LPI-Observer indicated that teachers rated their principal high in all areas of leadership. This result is not consistent with the findings of Kursunoglu and Tanriogen (2009) who reported that teachers have evaluated the leadership behaviors of their principals moderate. The results are somewhat consistent with LPI-Observer reported means reported by Kouzes and Posner (2003) for the general population. From the perspective of teachers, there is no significant relationship between none of the components of leadership behavior and management experience of principals. In other words, leadership behaviors of both experienced and inexperienced principals are relatively the same and generally acceptable. This is consistent with the findings of Johnson (2004) who showed that there is no significant relationship between experience and leadership behaviors of managers.

The analysis of data from the LPI-Self indicated that principals rated themselves very high in all areas of leadership which is inconsistent with the results of Long (1991) who stated that empowering others is the most important leadership strategy in order to achieve the best personal performance and other priorities, in order of preference, include inspiring a shared vision, modeling, reassuring, and challenging. The results in this study also are partially consistent with LPI-Self reported means for the general population reported by Kouzes and
Posner (2003). From the perspective of principals, there is no significant relationship between none of the components of leadership behaviors and management experience of principals. In other words, leadership behaviors of both experienced and inexperienced principals are relatively the same and generally acceptable. This is consistent with the findings of Johnson (2004) who showed that there is no significant relationship between experience and leadership behaviors of managers.

The results showed that there is no significant difference between self-reported leadership behaviors by the principals and those observed by teachers on enable others to act. In terms of other components a significant difference was found between self-reported leadership behaviors by the principals and those observed by teachers. The results of the present study showed that leadership behavior reported by principals and observed by teachers are at a favorable level which is consistent with the findings of Kozes and Posner (2001). This study suggested that principals have a better perception of their own leadership than teachers. The leadership behavior of modeling acquired the highest score among both principals and teachers which is not consistent with the findings of Pingle and Cox (2007). These results also were similar to the norms provided by Kouzes and Posner (2003) for the general population. This study found that principals view their own leadership behavior more favorably than the teachers perceive their principal's leadership behavior.

Although the leadership behaviors of principals were evaluated proper from by both principals themselves and teachers, principals gave higher scores to their own leadership behaviors in all components. Brubacher and Rudy (2005) believe that self-awareness and self-reflection allow leaders to have a better understand their own strengths and weaknesses and easier make changes in their own leadership behaviors. Managers may give high scores to their own performance because of lack of assessment skills and having a wrong understanding of selfassessment method. Managers should give honest answers to achieve a valid and authentic assessment. Kozes and Posner (2001) discuss honest responses in self-assessment and point out that managers should be honest with others in assessing their behaviors and the feedback in order to develop and improve their profession. By asking others, managers can better understand their own actions and behaviors of others. High awareness of managers acknowledges the necessity to increase leadership trainings under the title of self-awareness.

\section{Conclusion}

Although the scores teachers gave to leadership behaviors of principals were less than the scores principals gave to their own leadership behaviors, there scores were at an acceptable and satisfying level. It can be concluded that the greater variability in the teachers' observer ratings of their principal's leadership behavior indicate a more realistic perception of their principal's leadership behavior. This is supported by research which has revealed that a leader's effectiveness is largely determined by the perceptions of followers. According to Nye (2002) respective research suggests that "leadership is in the eye of the beholder". Kozes and Posner (2001) state that the skills a manager needs in this regard include development of cooperation and taking advantage of other people with a shared purpose and vision. Brubaker and Coble (2005) believed the self-awareness and self-reflection associated with this type of data collection allow leaders to make changes to their leadership behaviors by better understanding their strengths and weaknesses. Gonyea (2005) believed that self-reported data can generally be trusted but 
makes recommendations for using self-reported data in research. The leaders who empower others to act are actually making lively groups and get others actively involved in decisionmaking. They respect others and create an atmosphere of trust. This trust gives power and self-confidence to others and helps them obtain outstanding results. Getting the employees involved in decision-making has the greatest impact on student's achievement and teacher's morale. When teachers participate in decision-making, it gives them a sense of power and ability. Teachers can work and cooperate with principals in information exchange and resolving the issues related to the planning and providing educational programs to students. Authorities and officials are recommended do some measures such as transformation of the system of recruitment and preparation of schools principals with an emphasis on leadership behaviors and offer training courses on leadership behaviors. Undoubtedly, except researchers, school principals are the main addressee of the results of this study. Given the current situation in our country's schools, employing the teachers who are in line with the leadership behaviors of principals is very vital. In addition, principals can develop these beneficial behaviors in teachers by equipping themselves with leadership capabilities. Since a principal, in addition to monitoring the general affairs of a school, should play his/her management and leadership roles, it is suggested that educational managers be trained to modify their expectations of their duties and properly put into action the leadership and management behaviors. Training of managers should include opportunities for managers to learn more on selfassessment and their academic major. Managers should broad their knowledge on five styles of leadership proposed by Kozes and Posner (2001), because these styles represent the leadership behaviors of an effective management. This can be useful to managers because when they demonstrate the best practices, the organization members will act with the highest potential. Organizations and particularly education organization, to ensure that principals do their management task properly, inevitably should carefully review the character of principals before appointing them to managerial positions and somewhat ease their mind about proper and correct implementation of administrative tasks in schools by selecting the principals with desirable personality characteristics.

Finally, one of the most important limitations of this study is the use of self-reported data. Therefore, why scores obtained from self-reported data is greater than the scores observed data. The results of this type of research can be useful for managers, because they need a better understanding of their own leadership behaviors and using teachers' perception of leadership behaviors can be helpful.

\section{References}

Alaei, H. (2010) Comparative study of the importance of managerial and leadership behaviors from the perspective of teachers and principals; Master's thesis, Department of Educational Sciences, Faculty of Educational Sciences and Psychology, University of Sistan and Baluchestan

Alvani, M. (1993) Public Administration; Tehran, Nei Publication.

Ayman, R., and Chemers, M.M. (1983) The relationship of supervisory behavior ratings to work group effectiveness and subordinate satisfaction among Iranian managers. Journal of Applied Psychology, vol. 68, n. 4, pp. 338-341, http://dx.doi. org/10.1037/0021-9010.68.2.338
Berumen, J.C. (1992) Applying the Leadership Practices Inventory on Managers and Employees at Mexican Companies. A Dissertation Doctor of Education, Universidad Intercontinental (Mexico), Licenciado en Psychologies

Brubaker, D.L., and Coble, L.D. (2005) The hidden leader: Leadership lessons on the potential within. Thousand Oaks, CA: Corwin Press.

Brubacher, J. S., and W. Rudy. (2005) Higher Education in Transition: A History of American Colleges and Universities. New Brunswick, NJ: Transaction Publishers.

Carr, R.A. (1988) A comparative analysis of leadership attitudes of male and female California secondary public school principals. Thesis (Ed.D.), Loma Lina University, Dissertation Abstracts International, 48

Covey, S. (2005) Principal-centered leadership. New York: Free Press.

Dhanasobhon, C. (1982) Leadership styles of secondary school principals as perceived by selected principals and teachers in Bangkok, Thailand. Thesis (Ph.D.), the University of Oklahoma Fleishman, E.A., Mumford, M.D., Zaccaro, S.J., Levin, K.Y., Korotkin, A.L., and Hein, M.B. (1991) Taxonomic efforts in the description of leader behavior: A synthesis and functional interpretation. Leadership Quarterly, vol. 2, no, 4, pp. 245-287, http://dx.doi.org/10.1016/1048-9843(91)90016-U

Gonyea, RM. (2005) Self-reported data in institutional research: Review and recommendations. New Directions for Institutional Research, vol. 127, no. 1, pp. 73- 89, http://dx.doi.org/10.1002/ ir. 156

Goudarzi, M. H. (1996) A study on relationship between organizational climate and principals' behaviour effectiveness in government and private elementary schools in Babol (Iran). Thesis (M.Ed.), Allame University.

Jabor, K.M., Sale, M.I., Deba, A.A., Musta'mal, A.H., Sadiq, A. (2013) Responsibility of School's Leaders in Tackling the e-Learning Barriers in Technical and Vocational Education Higher Institutions, Journal on Efficiency and Responsibility in Education and Science, vol. 6, no. 3, pp. 134-142, http://dx.doi. org/10.7160/eriesj.2013.060301

Johnson, R.L. (2004) A study of instructional leadership behaviors of principals and student achievement. (Doctoral dissertation). Retrieved from ProQuest Digital Dissertations database

Kozes, J.M. and Posner, B.Z. (1999) Encouraging the Heart. San Francisco: Jossey

Kozes, J.M. and Posner, B.Z. (2001) Leadership Practice Inventory (LPI). Jossey Bass, San Francisco

Kouzes, J.M., and Posner, B.Z. (2002a) Leadership practices inventory: Theory and evidence behind the five practices of exemplary leadership.

Kouzes, J.M., and Posner, B.Z. (2002b) The leadership challenge (3rd ed.). San Francisco: Jossey-Bass.

Kouzes, J.M., and Posner, B.Z. (2003) Leadership Practices Inventory: Facilitator's Guide (3rd ed). San Francisco: JosseyBass.

Kouzes, J.M., and Posner, B.Z. (2006) A leader's legacy. San Francisco: Jossey- Bass.

Kouzes, J.M., and Posner, B.Z. (2007) The leadership challenge. San Francisco: Jossey-Bass.

Krejcie, R.V. and Morgan, D.W. (1970) Determining Sample Size for Research Activities. Educational and Psychological Measurement, vol. 30, no. 3, pp. 607-610 
Kursunoglu, A and Tanriogen, A. (2009). The relationship Between Teachers' Perceptions towards Instructional Leadership Behaviors of Their Principals and Teachers' Attitudes towards Change. Procedia - Social and Behavioral Sciences, vol. 1, no. 1, pp. 252-258, http://dx.doi:10.1016/j.sbspro.2009.01.046

Long, D.L. (1991) Identifying and Analyzing the Factors Utilized by Superintendents in Achieving Their "Personal Best" in Education. Doctoral Dissertation, Iowa State University Ames.

Manning, R.L. (2004) A Comparative Analysis of Leadership Skills: Military, Corporate, and Educational as a Basis for Diagnostic Principal Assessment. Doctoral Dissertation, Drexel University

Naeemollah, K. and Hafiz, I. (2010) The Managerial Behavior of Secondary School Heads in Punjab (Pakistan). Educational Research and Reviews, vol. 5, no. 4, pp. 189-192

Nye, JL. (2002) The eye of the follower: Information processing effects on attributions regarding leaders of small groups. Small Group Research, vol. 33, no. 3, pp. 337-360, http://dx.d oi.10.1177/10496402033003003

Pingle, T.L and Cox, E. P. (2007) Leadership Practices of Elementary School Principals. Curriculum Specialist South Carolina Department of Education Office of School Quality, Academic Leadership, vol. 4, no. 2, pp. 6-9.

Robinson, C.T. (1996) School effectiveness behaviors of elementary school principals in Mississippi. Thesis (Ph.D.), Jackson State University.

Satia, J. Kumar, A. and Liow M.L. (2014) Visionary Leadership in Health: Delivering Superior Value. SAGE Publications.

Tanner, J.R. (1981) Effects of leadership, climate and demographic factors on school effectiveness: An action research project in leadership development. Thesis (Ph.D.), Case Western Reserve University.

Umbach, H.N. (1993) Effects of sex, leadership style, and task structure on leadership effectiveness. Thesis (MS), Central Missouri State University. 